\title{
Free Fatty Acids Composition in Lipid Extracts of Several Sea Cucumbers Species from Malaysia
}

\author{
B. H. Ridzwan, M. H. Hanita, M. Nurzafirah, M. P. Siti Norshuhadaa, and Z. Farah Hanis
}

\begin{abstract}
The total lipid contents of local sea cucumbers; Holothuria scabra Jaeger, H. leucospilota Brandt, H. atra Jaeger and Stichopus horrens Selenka were determined with the respective results on dry matter basis $0.72 \%, 1.42 \%, 0.99 \%$ and $1.55 \%$. Meanwhile, the free fatty acids composition for each lipid extract showed all species contained arachidonic acid (C20:4n6) of polyunsaturated fatty acids (PUFA) of which $S$. horrens being the highest $42.41 \%$ followed by $H$. atra, $24.76 \%$, H. leucospilota, $23.23 \%$ and $H$. scabra, $19.63 \%$. H. scabra, $H$. leucospilota and $\boldsymbol{H}$. atra were rich in palmitic acid (C16:0) of saturated fatty acids (SFA); $52.66 \%, 35.63 \%$ and $34.21 \%$, respectively. Myristic acid (C14:0) of SFA was higher in $S$. horrens $(\mathbf{2 4 . 3 6 \% )}$. However, the fatty acids eicosapentanoic acid (EPA) [C20:5] were very low for all species; $\mathrm{H}$. scabra $(1.12 \%)$, H. leucospilota $(1.34 \%)$, H. atra $(0.17 \%)$ and S. horrens $(0.79 \%)$. Docosahexanoic acid (DHA) was only detected in S. horrens, i.e. $0.32 \%$. Thus, the results of this study indicated that different species of sea cucumber varies in its lipid content and free fatty acids composition.
\end{abstract}

Index Terms - Lipid, free fatty acids, sea cucumbers.

\section{INTRODUCTION}

Studies on nutritional effects of sea cucumber aroused interest when the locals claim that sea cucumbers could facilitate wound healing beside reducing gastric ulcer, inflammation, arthritis, pain, gout, ashtma, eczema, hypergycemia and hypertension [1]. Several retrospective studies supported some of these benefits [2]-[7]. Another promising new research of the potential effects of sea cucumber is its ability in the treatment of cancer. Sea cucumber contains saponin (triterpenoid) compounds that have anticancer properties [8]. Invitro studies showed these compounds inhibited several types of cancer cell growth including CEM-SS T-lymphoblastic cell [8], four human cancer cell lines; human non-small lung carcinoma (A549), human cervical cancer (C33A), human breast adenocarcinoma (MCF-7) and human esophageal cacinoma (TE1) [9]. Nevertheless, it is believed that lipid contents and their free fatty acids vary among sea cucumber species. Therefore, this study aimed to evaluate the lipid content and its free fatty acids composition of four respective sea cucumber species collected from coastal areas of Malaysia; Holothuria scabra Jaeger, H. leucospilota Brandt, $H$. atra Jaeger and Stichopus horrens Selenka.

Manuscript received January 24, 2014; revised March 19, 2014.

Ridzwan Hashim is with the International Islamic University Malaysia, Malaysia (e-mail: dr-ridzwan@yahoo.com).

\section{Materials AND MEthodS}

\section{A. Samples Collection}

Fresh samples of sea cucumber, H. scabra, H. leucospilota, $H$. atra and S. horrens were collected from coastal areas of Malaysia with the help of the Lembaga Kemajuan Ikan Malaysia (LKIM). The H. scabra came from Sulu Sea,Sabah while the other three species from the Strait of Malacca, Perak. Both locations are about $1000 \mathrm{Km}$ apart and are within Malaysia. The samples were packed immediately with ice prior sending to the laboratory and kept at $-80^{\circ} \mathrm{C}$ until further extraction.

\section{B. Determination of Total Lipid Content}

The sea cucumber lipid was extracted accordingly [10] with slight modification. The sea cucumbers were cleaned and their body walls were homogenized. The extraction process started with the sea cucumber tissues dried in an oven at $70^{\circ} \mathrm{C}$ until no change in mass was observed. The dried tissues were blended to produce fine powder, weighed before it was dissolved in $200 \mathrm{ml}$ of solvent mixture consisting of $200 \mathrm{ml}$ chloroform and $100 \mathrm{ml}$ methanol $(2: 1, \mathrm{v} / \mathrm{v})$. The mixture was then shaken in a shaker for $3 \mathrm{~h}$ before filtration. The filtrate was collected and the tissue residue was re-homogenized with $200 \mathrm{ml}$ solvent mixture of chloroform and methanol $(2: 1, \mathrm{v} / \mathrm{v})$ and shaken for another $3 \mathrm{~h}$, then filtered. The filtrate was collected while the final residue was re-homogenized with $200 \mathrm{ml}$ of chloroform and methanol, shaken for another $3 \mathrm{~h}$ and filtered. All filtrates were combined and evaporated using a rotary evaporator at $60^{\circ} \mathrm{C}$. Finally, the extracts were dried in a fume hood to produce a wax-like substance.

The lipid content ware determined by the given formula:

$$
\% F a t=\frac{\left(W_{3}-W_{2}\right)}{W_{1}} \times 100
$$

where:

$$
\begin{aligned}
& W_{1}=\text { sample weight }(\mathrm{g}) \\
& W_{2}=\text { extraction cup weight }(\mathrm{g}) \\
& W_{3}=\text { extraction cup }+ \text { residue weight }(\mathrm{g}) \\
& \text { C. Methylation and GC-MS Analysis of Sea Cucumber } \\
& \text { Lipid [11] }
\end{aligned}
$$

Fatty acids content of the lipid extracts were determined by methylation. $2 \mathrm{~g}$ of each lipid were dissolved in $50 \mathrm{ml}$ of chloroform in a $100 \mathrm{ml}$ volumetric flask, diluted further with chloroform until the mark $100 \mathrm{ml}$. Next, $1 \mathrm{ml}$ of the solution was transferred into $10 \mathrm{ml}$ capped tube. Under nitrogen $\left(\mathrm{N}_{2}\right)$ steam, the chloroform was removed until $100 \mu \mathrm{l}(0.1 \mathrm{ml})$ remained. Later, $1 \mathrm{ml}$ of boron trifluoride methanolic sodium 
hydroxide (Bf3-CH3OH) was added and the tube was flushed again with $\mathrm{N}_{2}$ steam and sealed. The tube was heated at $100^{\circ} \mathrm{C}$ in the water bath for $30 \mathrm{~min} .1 \mathrm{ml}$ hexane and $1 \mathrm{ml}$ distilled water were added into the tube which was then shaken vigorously for $2 \mathrm{~min}$ by hand. Finally, the hexane layer was removed into a vial for injection and analyzed via on-column GC technique using TurboMass 6890N gas chromatograph (TurboMass, Avondale, USA) equipped with a flame ionization detector (FID). A HP-5 non-polar capillary column (50m x $0.12 \times 0.5 \mathrm{~mm}$, SGE, Australia) was used and the temperature was initially kept at $50^{\circ} \mathrm{C}$ for $2 \mathrm{~min}$ and then programmed at $5^{\circ} \mathrm{C} \mathrm{min}^{-1}$ to $250^{\circ} \mathrm{C}$. The injector and detector temperatures were $220^{\circ} \mathrm{C}$ and $250^{\circ} \mathrm{C}$, respectively and helium gas was used as the carrier gas with a flow rate of 1.2 $\mathrm{ml} \mathrm{min}{ }^{-1}$. For identification of fatty acids in sea cucumber lipid, the GC-MS technique using TurboMass 6890N gas chromatograph coupled with a TurboMass 5973N mass selective detector (TurboMass, Avondale, USA) was used. The column and temperature conditions set were similar to that of GC analysis. The fatty acid constituents were recognized by comparing the MS spectrum to a standard library (Wiley Registry of Mass spectral data).

\section{RESULTS}

The lipid contents in $S$. horrens, $H$. leucospilota, $H$. atra and $H$. scabra were $1.55 \%, 1.42 \%, 0.99 \%$ and $H$. scabra $0.72 \%$, respectively. These results were in line with previous studies in which the total lipid content of most local sea cucumber was less than 2\% [12]. According to Tayoma and Tagaki [13], one main characteristic of sea cucumber is having low content of sterol lipids. However, the content of lipid in sea cucumber change with the season and location of this invertebrate animal.

The fatty acids compositions in 4 different species of sea cucumber were shown in Table I. The main saturated fatty acids (SFA) and polyunsaturated fatty acids (PUFA) found in $H$. scabra, H. leucospilota, and H. atra were palmitic acid (C16:0) and arachidonic acid (AA) (20:4), respectively. Holothuria scabra was also reported to contain testosterone [14] a hormone based lipid. This hormone is used for sex reversal on goods in which the male is economically more variable than a female, such as certain prawn and fish [15]. For S. horrens, the main SFA was myristic acid (C14:0) while the major PUFA still belong to arachidonic acid.

Holothuria scabra showed the highest percentage of palmitic acid, $52.66 \%$ followed by $H$. leucospilota, $35.63 \%$, $H$. atra $34.21 \%$ and $S$. horrens being the lowest $11.56 \%$. In contrast to palmitic acid, the highest percentage of arachidonic acid was detected in S. horrens comprising of $42.41 \%$. This was followed by $24.76 \%, 23.23 \%$ and $19.63 \%$ of arachidonic acid from $H$. atra, $H$. leucospilota and $H$. scabra, respectively.

Of the four sea cucumber species, myristic acid and palmitoleic acid (C16:1) were found highest in S. horrens where the percentage was $24.36 \%$ and $18.97 \%$, respectively. Meanwhile, myristic acid was lowest in $H$. leucospilota $(11.88 \%)$ while palmitoleic acid was lowest in $H$. atra (4.02\%). Only small percentage of stearic acid (C18:0) and oleic acid (C18:1) were detected in all species, i.e. less than
$4 \%$, except for $H$. leucospilota where the percentage of stearic acid was much higher, $22.06 \%$.

TABLE I: FATTY ACIDS COMPOSITION (\%) IN 4 SPECIES OF SEA CUCUMBERS LIPID EXTRACTS (-NOT DETECTED)

\begin{tabular}{|c|c|c|c|c|}
\hline \multirow{2}{*}{$\begin{array}{l}\text { Fatty acids } \\
\text { (trivial name) }\end{array}$} & \multicolumn{4}{|c|}{ Fatty acids (\%) in sea cucumber species } \\
\hline & $\begin{array}{c}H . \\
\text { scabra }\end{array}$ & $\begin{array}{c}H . \\
\text { leucospilota }\end{array}$ & H. atra & $\begin{array}{c}S . \\
\text { horrens }\end{array}$ \\
\hline 14:0 (myristic) & $\begin{array}{c}18.16 \pm \\
0.11\end{array}$ & $\begin{array}{c}11.88 \pm \\
0.27\end{array}$ & $\begin{array}{c}19.44 \pm \\
0.09\end{array}$ & $\begin{array}{c}24.36 \pm \\
0.19\end{array}$ \\
\hline 16:0 (palmitic) & $\begin{array}{c}52.66 \pm \\
0.06\end{array}$ & $\begin{array}{c}35.63 \pm \\
0.10\end{array}$ & $\begin{array}{c}34.21 \pm \\
0.03\end{array}$ & $\begin{array}{c}11.56 \pm \\
0.05\end{array}$ \\
\hline $\begin{array}{l}\text { 16:1 } \\
\text { (palmitoleic) }\end{array}$ & $\begin{array}{l}7.57 \pm \\
0.15\end{array}$ & $4.79 \pm 0.27$ & $\begin{array}{c}4.02 \pm \\
0.18\end{array}$ & $\begin{array}{c}18.97 \pm \\
0.17\end{array}$ \\
\hline 18:0 (stearic) & $\begin{array}{c}0.44 \pm \\
0.02\end{array}$ & $\begin{array}{c}22.06 \pm \\
0.11\end{array}$ & $\begin{array}{c}3.39 \pm \\
0.03\end{array}$ & $\begin{array}{c}0.37 \pm \\
0.02\end{array}$ \\
\hline 18:1 (oleic) & $\begin{array}{c}0.12 \pm \\
0.02\end{array}$ & $0.38 \pm 0.07$ & $\begin{array}{c}0.29 \pm \\
0.02\end{array}$ & $\begin{array}{c}0.87 \pm \\
0.14\end{array}$ \\
\hline 18:2 (linoleic) & - & - & $\begin{array}{c}13.71 \pm \\
0.04\end{array}$ & - \\
\hline 18:3 (linolenic) & $\begin{array}{c}0.31 \pm \\
0.03\end{array}$ & $0.69 \pm 0.04$ & - & $\begin{array}{c}0.34 \pm \\
0.07\end{array}$ \\
\hline $\begin{array}{l}20: 4 \\
\text { (arachidonic) }\end{array}$ & $\begin{array}{c}19.63 \pm \\
0.04\end{array}$ & $\begin{array}{c}23.23 \pm \\
0.08\end{array}$ & $\begin{array}{c}24.76 \pm \\
0.07\end{array}$ & $\begin{array}{c}42.41 \pm \\
0.10\end{array}$ \\
\hline $\begin{array}{l}20: 5 \\
\text { (eicosapentanoic } \\
\text { acid) }\end{array}$ & $\begin{array}{c}1.12 \pm \\
0.02\end{array}$ & $1.34 \pm 0.13$ & $\begin{array}{c}0.17 \pm \\
0.02\end{array}$ & $\begin{array}{c}0.79 \pm \\
0.04\end{array}$ \\
\hline $\begin{array}{l}22: 6 \\
\text { (docosahexanoic } \\
\text { acid) }\end{array}$ & - & - & - & $\begin{array}{c}0.32 \pm \\
0.04\end{array}$ \\
\hline
\end{tabular}

Three species contained low amount of linolenic acid (C18:3), i.e. H. scabra, H. leucospilota and S. horrens. Linolenic acid, however, could not be traced in $H$. atra. Small percentage of EPA [C20:5] comprising of less than $2 \%$ was detected in all 4 species where $H$. leucospilota being the highest, $1.34 \%$ followed by $H$. scabra, $1.12 \%$, S. horrens, $0.79 \%$. and $H$. atra being the lowest, $0.17 \%$. There was no docosahexanoic acid (DHA) [C22:6] traced in 3 species, except $S$. horrens where the composition was only $0.32 \%$. Evidence has proved that higher intakes of EPA and DHA lead to the low incidence of artery coronary heart disease and diabetes mellitus among the Eskimo whose diet consist of fish, seal and whale [1]. EPA is believed to exert its action through prostaglandin inhibition and anti-thrombic activity [16]. Meanwhile, linoleic acid (C18:2) was only found in $H$. atra, $13.71 \%$.

All four species of sea cucumber studied showed different percentages of saturated fatty acids (SFA), monounsaturated fatty acids (MUFA) as well as polyunsaturated fatty acids (PUFA) [Table II]. Saturated fatty acids were found dominated in H. scabra, H. leucospilota and H. atra; $71.26 \%$, $69.57 \%$ and $57.04 \%$, respectively. In $S$. horrens, the highest fatty acids detected were PUFA, $43.86 \%$. All species of sea cucumber studied showed lower amount of MUFA compared to SFA and PUFA. Total MUFA detected in three species, $H$. scabra, H. leucospilota and $H$. atra were $7.69 \%, 5.17 \%$ and $4.31 \%$, respectively while total MUFA traced in $S$. horrens was, $19.84 \%$. 
TABLE II: PERCENTAGES OF SFA, MUFA AND PUFA IN 4 SPECIE OF SEA CUCUMBER

\begin{tabular}{|l|c|c|c|c|}
\hline Fatty Acids & H. scabra & H. leucospilota & H. atra & S. horrens \\
\hline SFA & 71.26 & 69.57 & 57.04 & 36.29 \\
MUFA & 7.69 & 5.17 & 4.31 & 19.84 \\
PUFA & 21.06 & 25.26 & 38.64 & 43.86 \\
\hline
\end{tabular}

\section{DISCUSSION}

Previous studies have shown that sea cucumber contained bioactive substances that are believed to assist in wound healing and yet to be identified. Since sea cucumber feeds on bottom sediment, it should contain high levels of branched chain fatty acids, believed to be the substances that facilitate in wound repair [17]-[19]. Therefore, the fatty acids composition of sea cucumber in this study, especially PUFA of omega-3 $(\omega-3)$ and omega- $6(\omega-6)$ families will be of huge concerned.

In this study, four species of sea cucumber were selected; H. scabra, H. leucospilota, H. atra and S. horrens. All species chosen were commonly found in Malaysia. They are consumable. S. horrens has been recognised to contain substances that assist in wound healing [20]. Its ability to regenerate and heal itself after being cut and return to sea, has triggered the use of this sea cucumber species in wound healing [1]. Besides, its coelomic fluid is high in antioxidant activity [21]. The demand for this species as source of therapeutic agent is, therefore, high.

Of all PUFA, arachidonic acid ( $\omega-6$ acid) was the major fatty acids found in all the 4 species. This finding was supported by Svetashev et al. [22] who pointed out that the major fatty acids discovered in almost all species of sea cucumber was arachidonic acid while the total PUFA were higher than total SFA and MUFA [23]. The results obtained supported previous studies. According to Mat Jais et al. [24], arachidonic acid plays an important role in blood clotting thus serves as wound healing properties. The results also indicate that all the four species have the potential to be used as sources of $\omega-6$ fatty acid in human diet beside for medicinal purposes. However, except for $S$. horrens, arachidonic acid was found to be lower in all species studied.

Low percentage of EPA ( $\omega-3$ acid) was detected in all species and only traced amount of DHA ( $\omega-3$ acid) in $S$. horrens. Even though marine organisms are believed to contain higher EPA and DHA compared to freshwater organisms, the results in our study, however, could not be achieved. Previous study reported that sea cucumber contained high amount of EPA and DHA [25]. The difference could be attributed to locations of sampling and the kind of solvents used for lipid extraction. Holothuria leucospilota collected from Middle East, Iran contained $37.71 \%$ of EPA [25] compared to Malaysia, the percentage of EPA was only $0.17 \%$. Most animals could not synthesize longer chain of PUFA. They need these particular fatty acids from phytoplankton and some bacteria and transferred them through the food web [26], [27]. As explained, sea cucumber feeds on bottom sediments consisting of phytoplankton and bacteria rich in EPA and DHA. The locations of the sea cucumbers taken in this study, Kudat in Sabah and Pangkor Island in Perak could have low composition of phytoplankton and bacteria in their bottom sediments, thus lacked of EPA and DHA.

Fredalina and co-researchers [28] have also pointed out that different solvent extractions resulted in different amount of fatty acids composition in sea cucumber, Stichopus chloronotus. In their study, they found the percentages of EPA and DHA in methanol extracts were $5.83 \%$ and $1.20 \%$, respectively. This finding was much lower compared to phosphate buffered saline (PBS) and water extraction methods. EPA in PBS extraction method was $25.60 \%$ while DHA in water extraction method was $57.55 \%$. Therefore, the result obtained in our study seemed to validate previous study using the same solvent extraction, methanol. As far as EPA and DHA profiles are concerned, PBS was the best method of extraction in identifying the bioactive fatty acids in sea cucumber that assist in wound healing process [28].

All species of sea cucumber studied showed low percentages of EPA using methanol solvent for extract of lipid. Except for $S$. horrens, DHA was not detected in the other three species. However, high level of arachidonic acid in the extracts of all the four species could act as a precursor in the synthesis of EPA [29].

\section{CONCLUSION}

Lipid extracts of H. scabra, H. leucospilota, H. atra and $S$. horrens contained high, but variable amounts of arachidonic acid. However, only small amount of EPA was present in all four species, except DHA which was detected only in $S$. horrens. Therefore, it could be postulated that different sampling locations, environment factors and kind of solvent extractions play important roles in determining the composition of fatty acids in lipid extracts of sea cucumbers. All species of sea cucumber studied have the potential to be used as a source of omega- 6 fatty acids in human diet and for medicinal purposes. Omega- 6 fatty acids play important role in blood clotting, thus assist wound healing process.

Although not much omega acid are found in these species of sea cucumber, other edible species need to be determined for their omega acid contents since Malaysian water has more than 50 species of sea cucumbers [1]. Some of the species may be beneficial as source of therapeutic agents. On the other hand, continual studies should be focused on the mechanistic study of the effect of EPA and DHA in sea cucumber lipid on various aspects of wound healing and tissues repair.

\section{ACKNOWLEDGMENT}

Thanks to the Ministry of Science, Technology and Innovation (MOSTI) Malaysia, International Islamic University Malaysia, Benih Jaya Aqua Sdn Bhd and Hj. Zali Ibrahim, Lembaga Kemajuan Ikan Malaysia (LKIM) for supporting this study.

\section{REFERENCES}

[1] B. H. Ridzwan, Sea Cucumbers, A. Malaysian Heritage, 1st Ed Research Management Centre of International Islamic University 
Malaysia (IIUM): Kuala Lumpur Wilayah Persekutuan, Malaysia. pp. 2, 2010.

[2] B. H. Ridzwan, B. I. Mohd Noor, B. I. Norhayati, M. A. Kaswandi, and M. B. O. Rozali, "Timun laut (holothuroid) Sabah. Jus kasar beberapa spesies sebagai penyembuh luka aruhan," $7^{\text {th }}$ National Seminar on Natural Products Universiti Sains Malaysia and Institute Kimia Malaysia (Utara), Jan. 27-28 ${ }^{\text {th }}$, 1990, pp. 204-209.

[3] B. H. Ridzwan et al., "The effect of Stichopus hermanii coelomic fluid on antigen-induced arthritis in guinea-pigs," The Science Conference 2001 Yemeni Scientific Research Foundation, Oct. 11-13 ${ }^{\text {th }}, 2001$, Sana'a Yemen.

[4] B. H. Ridzwan, T. C. Leong, and S. Z. Idid, "The antinoceptive effects of water extracts from sea cucumber Holothuria leucospilota Brandt, Bohadschia marmorata vitiensis Jaeger and coelomic fluid from Stichopus hermanni," Pakistan J Bio Sc., vol. 6, no. 24, pp. 2068-2072, 2003.

[5] M. Nihayah, R. Yanti, A. R. Nur Afiah, A. B. Azman, and B. H. Ridzwan, "The healing effects of Stichopus variegatus extract on induced gastric lesion of rats," Pasca Simp. Sains Kesihatan Kebangsaan Ke-3, Universiti Kebangsaan Malaysia, Kuala Lumpur, pp 259-263, April 29-30, 2000.

[6] M. S. N. Ibrahim, W. M. Norizam, and B. H. Ridzwan, "Effects of crude holothuroid extract on fructose-induced hypertensive rats," Asia Pacific J Pharmacol., vol. 15, Suppl 1, 2001.

[7] W. T. Tan, Y. S. Fong, and B. H. Ridzwan, "The effect of ceolomic fluid Stichopus hermanii on isolated perfused rat heart and the involvement of prostaglandin in its mechanism of action," Pakistan $J$ Bio Sc., vol. 8, no. 1, pp. 78-84, 2005.

[8] M. A. Kaswandi, H. L. Hing, A. Z. Sahalan, F. Farah, B. H. Ridzwan, M. W. Samsudin, M. S. M. Yasin, and A. Abd Manaf, "Saponin from sea cucumber Stichopus badionotus Sluiter as potential cytotoxic agent on CEM-SS T-lymphoblastic cell," J Microscopy Soc. Thailand, vol. 18, no. 1, pp. 79-84, 2004.

[9] O. Y. Althunibat, B. H. Ridzwan, M. Taher, M. D. Jamaludin, and S. J. A. Ichwan, and N. Qaralleh, "Antioxidant and cytotoxic properties of two sea cucumbers, Holothuria edulis Lesson, and Stichopus horrens Selenka," Hungarica Acta Biologica J., vol. 60, no. 1, pp. 10-20, 2013.

[10] J. Folch, M. Lee, and G. H. Stanley, "A simple method for the isolation and purification of total lipids from animal tissues,"J Bio Chem., vol. 226, pp. 497-496, 1957.

[11] M. Evlogieva, D. Danalev, D. Tanev, L. Vezenkov, and B. Damianova, "Investigation of Fatty Acids Composition in Food Additives using Gas Chromatography-Mass Spectrometry," J Univ. Chem. Tech. Metallurgy, vol. 45, no. 1, pp. 87-92, 2010.

[12] B. H. Ridzwan, Sumber Makanan Pesisiran Laut Sabah, Pub. Dewan Bahasa \& Pustaka, Kementerian Pendidikan Malaysia, Kuala Lumpur, pp. 309, 1993.

[13] Y. Tayoma and T. Tagaki, "Sterols and other unsaponifiable substances in lipid of shellfish, crustacean and echinoderms XV. Occurrence of $\ddot{A}^{7}$ cholesterol as a sterol components of starfish Asterias amurensis Lutken," Bull. Chem. Soc. Jap., vol. 27, p. 421, 1995.

[14] K. H. Dewi, D. Silsia et al., "Pengaruh Kecepatan Sentrifugasi pada proses pemisahan hasil ekstrak teripang pasir (Holothuria scabra) sebagai sumber testosteron alami dan antigen," Prosiding Seminar Nasional Teknik Kimia 'Kejuangan'. Pengembangan Teknologi Kimia untuk Pengolahan Sumber Daya Alam Indonesia, Yogyakarta, 26 Januari 2010.

[15] R. Etty et al., "Permanfaatan steroid teripang sebagai aprodisiaka alami dan untuk pengembangan budidaya perikanan," Laporan eksekutif hibah penelitian pascasarjana-HPTP. ITB, 2008.

[16] K. D. Croft, L. J. Beilin, F. M. Legge, and R. Vandongen, "Effects of diets enriched in eicosapentaenoic or docosahexanoic acids on prostanoic metabolism in the rat," Lipids, vol. 22, no. 9, pp. 647-650, 1987.

[17] J. R. Sargent, C. C. E. Hopkins, J. V. Seiring, and A. Youngson, "Partial characterization of organic material in surface sediments from Balsfjorden, Northern Norway in relation to its origin and nutritional value for sediment-ingesting animals," Mar Biol., vol. 76, pp. 87-94, 1983.

[18] N. W. Philips, "Role of different microbes and substrates as potential suppliers of specific, essential nutrients to marine detritus," Bull Mar Sci., vol. 35, pp. 283-298, 1984.

[19] R. F. Leo and P. L. Parker, "Branched-chain fatty acids in sediments," Science, vol. 152, pp. 649-650, 1996.

[20] B. H. Ridzwan, H. Fadzil, M. Y. H. Azman, and H. L. Sharif, "The effectiveness of different medium of extracts of local sea cucumbers on induced wounds," presented at $2^{\text {nd }}$ Asean Conference on Medical Science, Medan, Indonesia, August 17-20, 2002.

[21] I. Hawa et al., "The potential of the coelomic fluid in sea cucumbers as an antioxidant," Malaysian J Nutr., vol. 5, pp. 55-56, 1999.

[22] V. L. Svetashev, V. S. Levin, N. L. Cham, and T. N. Do, "Lipid and fatty acid composition of holothurians from tropical and temperate waters," Comp. Biochem. Physiol., vol. 4, pp. 489-494, 1991.

[23] M. Aydin, H. Sevgili, B. Tufan, Y. Emre, and S. Kose, "Proximate composition and fatty acid profile of three different fresh and dried commercial sea cucumbers from Turkey," Inter J Food Sci Tech., vol. 46, no. 3, pp. 500-508, 2011.

[24] A. M. M. Jais, R. McCulloch, and K. Croft, "Fatty acid and amino acid composition in haruan as a potential role in wound healing," Gen. Pharmacol., vol. 25, no. 5, pp. 947-950, 1992.

[25] Y. Maziar, A. Majid, J. Ali, E. Maryam, K. Aida, K. Reza, and M. Amin, "Fatty acid composition in two sea cucumber species, Holothuria scabra and $H$. leucospilota from Qeshm Island (Persian Gulf)," African J Biotech, vol. 11, no. 2, pp. 2862-2668, 2012.

[26] J. K. Volkman, S. W. Jeffrey, P. D. Nichols, G. I. Rogers, and C. D. Garland, "Fatty acid and lipid composition of 10 species of microalgae used in mariculture," J Exp. Mar. Biol. Ecol., vol. 128, pp. 219-240, 1989.

[27] M. R. Brown, G. A. Dunstan, S. W. Jeffrey, J. K. Volkman, S. M. Barrett, and J. M. LeRoi, "The influence of irradiance on the biochemical composition of the Pyrmnesiophyte isochrsis sp. (clone t-iso)," J Phycol, vol. 29, pp. 601-612, 1993.

[28] B. D. Fredalina, B. H. Ridzwan, A. A. Z. Abidin, M. A. Kaswandi, H. Zaiton, I. Zali, P. Kittakoop, and A. M. M. Jais, "Fatty acid compositions in local sea cucumber, Stichopus chloronotus, for wound healing," J Gen Pharmacol., vol. 33, no. 4, pp. 337-340, 1999.

[29] W. C. Bowman and M. J. Rand, Textbook of Pharmacology, $2^{\text {nd }}$ Ed. Melbourne: Blackwell Sci. Pub. Oxford, pp. 270-272, 1980.

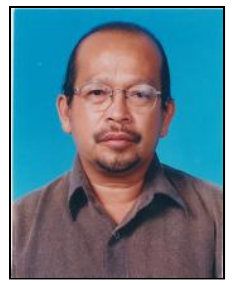

Ridzwan Hashim was born in Nipah, Bachok, Kelantan in 1951. He received the Diploma Agriculture from College of Agriculture Malaya, Serdang, Malaysia (1972) and pursued his Bachelor of Science from Louisiana State University (1974) and Master of Science from University of Arkansas, USA (1976). In 1982, he was awarded the Doctor of Philosophy from School of Pharmaceutical Sciences, University of Strathclyde, Scotland.

He started as a science teacher in Arabic School Pasir Mas (1969) and as a General Manager of Farmer's Association, Bukit Jawa, Kelantan (1972). In 1976, he started his academic career in Universiti Kebangsaan Malaysia (UKM) and was appointed as Resident Principal of the Clinical College (1977-79). Later, the Head of Biology as well as the Head of the Unit of Marine Science, Faculty of Science and Natural Resources, UKM, Sabah. In 1990, he managed as Deputy Dean Academic and Research (1990-1993). Upon an optional retirement in 2002, he was invited to establish the Biomedical Science Program in the Kulliyyah of Science, International Islamic University Malaysia (IIUM) in Gombak campus. Currently, he serves as a professor of Biomedical Science, Kulliyyah of Allied Health Sciences, IIUM Kuantan campus. His interest in the sea cucumber and other marine resources started in early 1983 when he was serving UKM Sabah Campus. He received several grants under Ministry of Science and Technology Malaysia to study sea cucumber in Malaysia water. 